Reprod. Nutr. Dévelop., 1987, 27 (4), 829-839.

\title{
Body composition, metabolic rate and utilization of milk nutrients in suckling piglets
}

\author{
J. NOBLET, M. ETIENNE
}

with the technical assistance of Annick BLANCHARD, Martine FILLAUT, Nadine MEZIERE, Christiane VACHOT and S. DUBOIS

Station de Recherches Porcines, I.N.R.A., Saint-Gilles, 35590 L'Hermitage, France.

Summary. The oxygen $\left(\mathrm{O}_{2}\right)$ consumption, carbon dioxide $\left(\mathrm{CO}_{2}\right)$ production, heat production (HP) and milk nutrient intake of 22 litters of suckling piglets were recorded every 4 days from the day after birth to weaning at 22 days of age. At weaning, 147 representative piglets of these litters were slaughtered to measure their chemical composition and to calculate the energy and nutrient balance of individual piglets and litters between birth and weaning. $\mathrm{O}_{2}$ consumption, $\mathrm{CO}_{2}$ production and $\mathrm{HP}$ were constant over the suckling period when expressed per $\mathrm{kg}$ of body weight ${ }^{0.68}\left(\mathrm{BW}^{0.68}\right) ; \mathrm{O}_{2}$ consumption and $\mathrm{HP}$ averaged 34.4 liters and $168 \mathrm{kcal}$ per $\mathrm{kg}$ of $\mathrm{BW}^{0.68}$ and per day, respectively. The respiratory quotient (RQ) $\left(\mathrm{CO}_{2} / \mathrm{O}_{2}\right)$ was 0.84 . Average daily gain between birth and weaning (ADG) ranged from 35 to $285 \mathrm{~g}$ (mean : $186 \mathrm{~g}$ ). Dry matter, fat and energy contents of piglets at weaning were positively correlated with ADG while protein and ash contents were negatively correlated with ADG. The daily amounts of protein, fat, ash and energy deposited were linearly related to ADG, so that the chemical composition of additional gain was constant : $410,141,197$ and $28 \mathrm{mg} / \mathrm{g}$ and $2960 \mathrm{cal} / \mathrm{g}$ for dry matter, protein, fat, ash and energy, respectively. The deposition of $1 \mathrm{~g}$ of protein or fat was associated with 5.20 or $1.17 \mathrm{~g}$ of weight gain, respectively. Finally, $55 \%$ of the energy and $85 \%$ of the nitrogen supplied by milk were retained in piglet weight gain.

\section{Introduction.}

Changes in the chemical composition of young pigs over the suckling period have been studied by many authors (Berge and Indreb $\phi, 1954$; Manners and McCrea, 1963 ; Elsley, 1964 ; Robelin et al., 1984). However, there is little information on the relationship between chemical composition at weaning and changes in milk nutrient supply or intensity of growth during the suckling period. In addition, no information is available on the efficiency of the energy, protein and fat of sow's milk for deposition in the piglet body.

In energy metabolism studies on suckling piglets, it is necessary to separate the gas exchanges of the litter from those of the sow. This methodological diffi- 
culty explains why such studies are rare. The only available results on metabolic rate or nutrient balance of piglets have been limited to the first days of life (Mount, 1968 ; Gentz et al., 1970) and, in most cases, were obtained on piglets given milk replacers (Campbell and Dunkin, 1983).

The objectives of the present experiment were therefore to quantify the modifications of body composition at weaning associated with variations in growth rate and to measure the metabolic rate of piglets over the suckling period. Milk intake was also measured in order to establish the energy, nitrogen and fat balance and to assess the efficiency of the utilization of milk nutrients for deposition in the piglet body.

\section{Material and methods.}

\section{Experimental design.}

Twenty-two primiparous Large White sows were used. During lactation, onehalf of them were fed a normal energy level (14.2 Mcal ME/day) and the others a restricted one (10.4 Mcal ME/day). The diets, based on cereals and soybean meal, were formulated to supply similar daily amounts of protein, amino acids, minerals and vitamins. After farrowing, litter size was standardized to 9 or 10 piglets. Piglet milk consumption was measured according to the weigh-suckleweigh technique on the day after farrowing (day $1=d 1$ ) and on d5, d9, d13, d17 and d21. Milk composition was determined on the days after the measurement of milk production. The piglets had no access to the sow's food or to creep feed during the experimental period. The sow diets, housing conditions and calculation of nutrient production in milk have been described in detail by Noblet and Etienne (1986, 1987).

\section{Measurements.}

2.1. Metabolic rate. - On the days milk intake was measured, the piglets were removed from the sows between $7.00 \mathrm{a} . \mathrm{m}$. and $8.00 \mathrm{p} . \mathrm{m}$. They were allowed to suckle every $72 \mathrm{~min}$. Oxygen $\left(\mathrm{O}_{2}\right)$ consumption and carbon dioxide $\left(\mathrm{CO}_{2}\right)$ production of the suckled piglets were measured during the intervals between sucklings, every two sucklings ( 5 measurements per day), in a group of 3 to 10 littermate piglets. Each piglet was measured at least twice a day. They were kept in a confinement chamber in which the temperature was reduced progressively from $29^{\circ} \mathrm{C}$ at $\mathrm{d} 1$ to $25^{\circ} \mathrm{C}$ at $\mathrm{d} 21$. The ambient temperature was supposed to be at or above the critical temperature of suckled piglets (Mount, 1968) and close to the climatic conditions when with the sow. The measurement of $\mathrm{O}_{2}$ consumption and $\mathrm{CO}_{2}$ production commenced between 5 and $10 \mathrm{~min}$ after suckling and lasted 50 to $55 \mathrm{~min}$. Gas exchanges were calculated according to the method of Noblet and Le Dividich (1981). For each measurement day, the average gas exchanges of the piglets in a litter $\left(\mathrm{ml} . \mathrm{kg}\right.$ litterweight $\left.{ }^{-1} \cdot \mathrm{min}^{-1}\right)$ were estimated as the mean of the five daily measurements $\left(\mathrm{ml} . \mathrm{kg} \mathrm{piglet}^{-1} \cdot \mathrm{min}^{-1}\right)$. 
Gas exchanges of the litter over the whole lactation (d1 to d21) were then calculated (Noblet and Etienne, 1987). Corresponding heat production (HP) was obtained by Brouwer's formula (1965).

2.2. Body composition. - On the morning of d22 (weaning), the piglets were separated from the sow and weighed individually after a 2-hour fast. Four to 10 piglets in each litter were then sacrificed by chloroform asphyxia. A total of 147 piglets were slaughtered. After the digestive tract was emptied and put back in the carcass, the piglets were frozen for subsequent mincing and homogenization. Representative samples of the carcasses were freeze-dried and analysed for dry matter, ash, nitrogen (macro-Kjeldahl), fat (Bligh and Dyer, 1959) and energy (adiabatic bomb calorimetry). The mean characteristics of the slaughtered piglets are presented in table 1. Energy and nutrient deposition between birth and weaning were calculated for each piglet, assuming that dry matter, nitrogen, ash, fat and energy contents at birth were $190,18.4,35,12 \mathrm{~g} / \mathrm{kg}$ and $860 \mathrm{cal} / \mathrm{g}$, respectively (Noblet and Etienne, 1986).

TABLE 1

Body weight, growth rate and nutrient gain of suckled piglets between birth and weaning at 22 days of age $(n=147)$.

\begin{tabular}{lcc}
\hline \multicolumn{1}{c}{ Item } & Mean (SE) & Range \\
\hline Body weight & & \\
Body weight (BW) at birth (g) & $1249(207)$ & $804-1792$ \\
BW at 22 days (g) & $5248(1159)$ & $1628-7329$ \\
Empty BW at weaning (\% BW) & $96.82(.83)$ & $93.39-98.88$ \\
Empty digestive tract \% empty BW & $5.25(.64)$ & $3.86-8.13$ \\
Growth rate & & \\
ADG (g/day) & $186(46)$ & $35-285$ \\
Empty ADG (g/day) & $178(45)$ & $33-269$ \\
Chemical composition ${ }^{\text {b }}$ & & \\
Dry matter (\%) & $31.75(2.60)$ & $23.54-37.11$ \\
Proteins (N $\times 6.25, \%)$ & $14.85(.49)$ & $13.69-16.38$ \\
Lipids (\%) & $11.26(2.42)$ & $3.02-15.89$ \\
Ash (\%) & $3.05(.19)$ & $2.12-3.69$ \\
Energy (cal/g) & $2058(247)$ & $1225-2487$ \\
Daily nutrient gain ${ }^{\mathrm{c}}$ & & \\
Dry matter (g) & & \\
Proteins (g) & $64.8(18.7)$ & $9.8-101.8$ \\
Lipids (g) & $28.2(6.4)$ & $7.3-40.0$ \\
Ash (g) & $26.7(9.4)$ & $1.8-44.8$ \\
Energy (cal) & $5.1(1.3)$ & $1.2-9.1$ \\
\hline
\end{tabular}

a Standard error ; ${ }^{b}$ Chemical composition of empty BW at weaning; ${ }^{c}$ Between birth and weaning.

2.3. Calculation. - The data on the chemical composition of the piglets at weaning were submitted to covariance analysis with the average daily gain between birth and weaning ( $A D G)$ and the body weight at birth $\left(B W_{o}\right)$ as covariates and the energy level of the lactating sow, the sex and litter origin of the piglets as main effects (table 2). Adjustment slopes of covariates were used to 
predict the chemical composition at weaning of unslaughtered littermates. The difference between energy and nutrient contents at $\mathrm{d} 22$ and $\mathrm{d} 1$ (comparative slaughter technique) provided estimates of daily energy $\left(E R_{S T}\right)$ and nutrient balance of the litter from d1 to weaning. Body composition was assumed to be comparable at birth and the morning of d1. A second estimate of litter energy balance over lactation (ER $R_{R O}$ ) was obtained by subtracting HP (calculated from gas exchanges; $R Q$ method) from metabolizable energy intake as milk (equivalent to energy intake as milk $\times 0.95$; Jordan and Brown, 1970). Estimates of both $E R_{\mathrm{ST}}$ and $\mathrm{ER}_{\mathrm{RO}}$ were obtained for 20 litters (average litter size : 9.5 piglets).

2.4. Statistical analysis. - Regression equations between chemical composition at weaning and $A D G$ and $B W_{0}$ were calculated. In addition, the effect of the energy level of the sow and the litter origin of the piglets (piglets born from the same sow) were considered in these equations. Similar calculations were done for the energy and nutrient balance of piglets between $\mathrm{d} 1$ and weaning. Gas exchanges data were submitted to variance analysis with the energy level of the sow diet and lactation stage as main effects. The consequences of energy level in the sow diet on the chemical composition of piglets at weaning, milk nutrient output and piglet nutrient balance have been presented elsewhere (Noblet and Etienne, 1986). The present results were therefore obtained using pooled data.

\section{Results and discussion.}

\section{Body composition.}

Mean results on the body composition of the 22-day old suckling piglets in the present experiment (table 1) were similar to those reported by Elsley (1964). The results of the present experiment however demonstrate that piglet chemical composition was affected by (1) the energy level of the sow via an effect on milk composition (table 2 ; Noblet and Etienne, 1986), (2) by the litter origin of the

TABLE 2

Effect of energy restriction of the sow during lactation and litter origin of piglets on chemical composition of empty body weight of piglets at weaning at 22 days of age (Adjusted means ${ }^{\mathrm{a}}$ ).

\begin{tabular}{|c|c|c|c|c|c|c|}
\hline Item & $\begin{array}{c}\text { Energ) } \\
\text { Normal } \\
(\mathrm{n}=70)\end{array}$ & $\begin{array}{l}\text { Y level } \\
\text { Restricted } \\
(n=77)\end{array}$ & $\begin{array}{l}\text { Slopes for } \\
\text { ADG }\end{array}$ & $\begin{array}{c}\text { adjustment }^{\mathrm{b}} \\
\mathrm{BW}\end{array}$ & $\mathrm{RSD}^{\mathrm{c}}$ & $\begin{array}{c}\text { Statistical } \\
\text { significance }^{d}\end{array}$ \\
\hline \multicolumn{7}{|l|}{ Chemical composition } \\
\hline $\begin{array}{l}\text { Dry matter }(\%) \\
\text { Protein }(\%) \\
\text { Lipid }(\%) \\
\text { Ash }(\%) \\
\text { Energy }(\mathrm{cal} / \mathrm{g})\end{array}$ & $\begin{array}{r}31.49 \\
14.92 \\
10.86 \\
3.05 \\
2024\end{array}$ & $\begin{array}{r}32.17 \\
14.82 \\
11.82 \\
3.09 \\
2102\end{array}$ & $\begin{array}{r}47.3(3.6) \\
-3.5(1.0) \\
40.0(2.8) \\
-2.0(0.4) \\
4560(251)\end{array}$ & $\begin{array}{l}-3.9(1.0) \\
\text { NS } \\
-4.1(0.6) \\
\text { NS } \\
-343(60)\end{array}$ & $\begin{array}{c}1.04 \\
0.43 \\
0.95 \\
0.17 \\
97\end{array}$ & $\begin{array}{l}\mathrm{E}^{*} \mathrm{O}^{* *} \mathrm{ADG}^{* *} \mathrm{BW}_{\mathrm{o}}^{* *} \\
\mathrm{O}^{* *} \mathrm{ADG}^{* *} \\
\mathrm{E}^{* *} \mathrm{O}^{* *} \mathrm{ADG}^{* *} \mathrm{BW}_{\mathrm{o}}^{* *} \\
\mathrm{O}^{* *} \mathrm{ADG}^{* *} \\
\mathrm{E}^{* *} \mathrm{O}^{* *} \mathrm{ADG} \mathrm{B}^{* *} \mathrm{BW}_{\mathrm{o}}^{* *}\end{array}$ \\
\hline
\end{tabular}

Adjusted means from covariance analysis with energy level of lactating sow (E) and origin (O) as main effects and average daily gain ( $A D G, \mathrm{~kg} / \mathrm{day}$ ) and body weight at birth ( $B W_{\mathrm{o}}$ ) as covariates. The results were not significantly affected by sex; b Slope and standard deviation (in parenthesis); c Residual standard deviation; a Levels of significance : ** $P<0.01$; $P<0.05$; NS P $>0.10$. 
piglets and (3) to a large extent by ADG (table 3 ). Compared to artificially reared piglets fed an adequate protein diet and having a similar growth rate (Campbell and Dunkin, 1983), body protein colitent was lower and fat content higher in the present experiment. This difference is due to the protein : energy ratio which is higher in artificial milk than in sow's milk (59 vs $40 \mathrm{~g} / \mathrm{Mcal}$ ) and to the higher fat intake of suckled pigs. As in growing pigs (Campbell et al., 1985), protein and ash contents were negatively correlated to ADG. On the other hand, dry matter, fat and energy contents were positively correlated with ADG. In addition, they were negatively correlated to body weight at birth. This means that for a same growth rate, piglets that were light at birth were comparatively fatter at weaning than heavier ones. Finally, sex had no significant effect on body composition.

The present results suggest that the chemical composition of piglets at weaning can be accurately predicted from $A D G$ and $B W_{0}$ since the variation coefficient was about 3 and $12 \%$ for protein and fat contents, respectively (table 3). Nevertheless, the results in table 2 show that the prediction of chemical composition at weaning was significantly improved when litter origin and the nutritional status of the sow (i.e. milk composition) where taken into account since the residual standard deviation for dry matter, fat or energy content was about $30 \%$ lower. In practice, chemical composition at weaning can be accurately predicted from the chemical analysis of a few representative piglets within a litter in order to estimate the intercept of the regression equation. The coefficients for $A D G$ and $\mathrm{BW}_{0}$ (table 2) could thus be used to predict the chemical composition of unslaughtered littermates according to their actual growth rate and body weight at birth.

Changes in chemical composition at weaning with the ADG were the consequence of the deposition rates of protein and fat which were found to change with ADG (fig. 1). Each gram increase of empty $A D G\left({ }_{E} A D G\right)$ in the present experiment was associated with $410( \pm 7) \mathrm{mg}, 141( \pm 2) \mathrm{mg}$, $28( \pm 1) \mathrm{mg}, 197( \pm 6) \mathrm{mg}$ and 2960 ( \pm 59) cal of deposited dry matter, protein, ash, fat and energy, respectively. In addition, no significant quadratic

\section{TABLE 3}

Relationship between daily body weight gair from birth to weaning at 22 days of age (ADG, $\mathrm{kg}$ ), body weight at birth $\left(B W_{o} \mathrm{~kg}\right.$ ) and chemical composition $(Y)$ of the empty body of piglets at weaning : $Y=a+b \cdot A D G+c . B W_{o}(n=147)$.

\begin{tabular}{lrrrrr}
\hline \multicolumn{1}{c}{$Y$} & $\mathrm{a}$ & \multicolumn{1}{c}{$\mathrm{b}^{\mathrm{a}}$} & $\mathrm{c}^{\mathrm{a}}$ & $\mathrm{R}^{\mathrm{b}}$ & $\mathrm{RSD}^{\mathrm{c}}$ \\
\hline Dry matter (\%) & 23.54 & $44.2(2.8)$ & & 0.79 & 1.60 \\
& 26.89 & $49.8(2.8)$ & $-3.5(0.6)$ & 0.83 & 1.45 \\
Protein $(\mathrm{N} \times 6.25)(\%)$ & 15.77 & $-5.0(0.8)$ & & 0.48 & 0.43 \\
Lipid (\%) & 3.59 & $41.3(2.6)$ & & 0.79 & 1.48 \\
& 6.45 & $46.1(2.6)$ & $-3.0(0.6)$ & 0.83 & 1.36 \\
Ash (\%) & 3.31 & $-1.4(0.3)$ & & 0.33 & 0.18 \\
Energy (cal/g) & 1245 & $437(250)$ & & 0.82 & 140 \\
& 1514 & $4821(247)$ & $-281(55)$ & 0.85 & 129 \\
\hline
\end{tabular}

a In parenthesis, standard deviation of regression coefficients ; ${ }^{b}$ Correlation coefficient ; ${ }^{c}$ Residual standard deviation. 


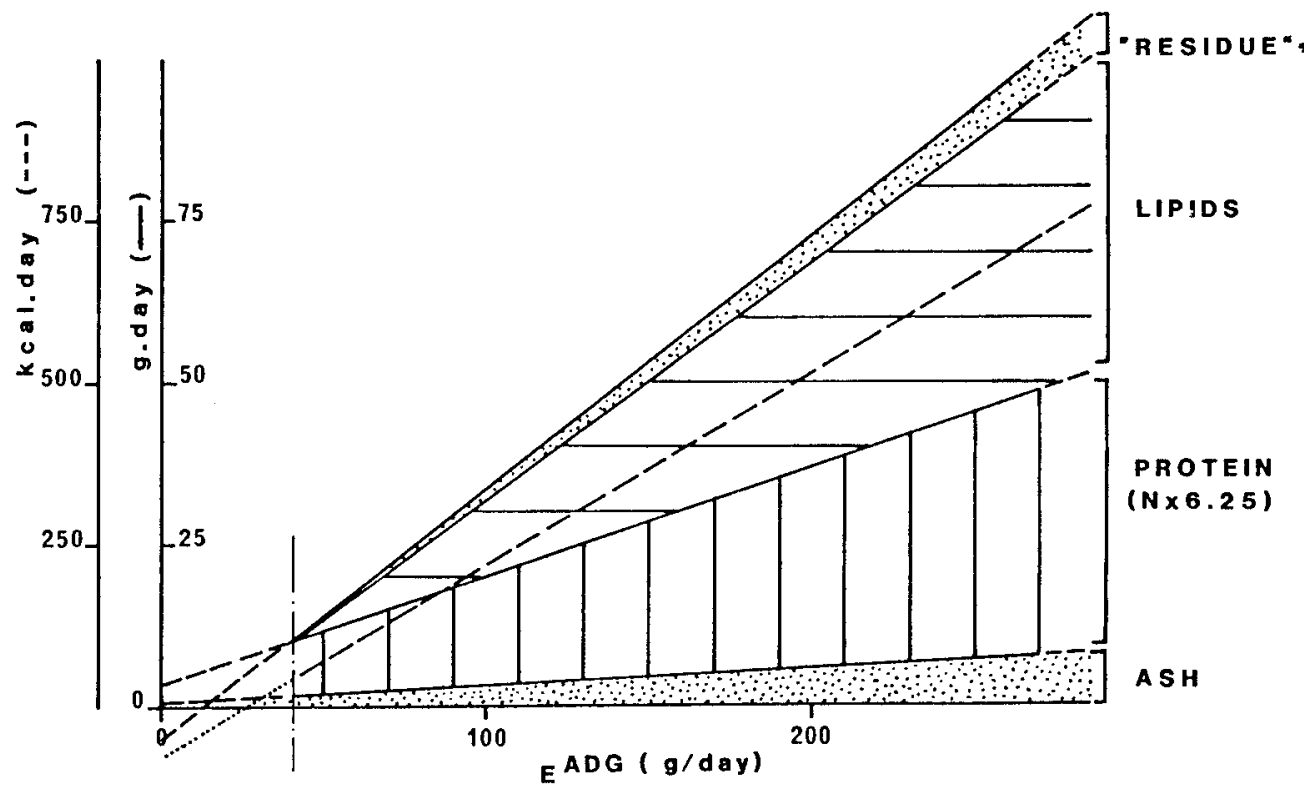

FIG. 1. - Effect of daily empty growth rate between birth and weaning at 22 days of age on the deposition of nutrients ( $\mathrm{g} /$ day) and energy ( $\mathrm{kcal} / \mathrm{day})$ in suckling piglets. "Residue " corresponds to the difference between dry matter and ash + protein + lipid deposition.

effect of ${ }_{E} A D G$ on nutrient balance was observed. The consequence was that the chemical composition of additional daily gain was constant whatever the value of ADG. This finding contrasts with observations on older pigs (Campbell et al., 1985). In the latter experiment, the energy or fat content of additional body weight gain, due to a higher feeding level, increased as the ADG augmented. This change was associated with a reduced protein content of additional gain, daily nitrogen retention having plateaued at high feed intake. The potential for protein accretion in growing-fattening pigs is thus limited, whereas in suckling piglets the potential appears to be located beyond the energy intake allowed even by high milk intake. In addition, the suckling piglets retained milk nitrogen with a very high efficiency since about $85 \%$ of the nitrogen intake was deposited in the body (table 4). The fact that this value is similar to that of Campbell and Dunkin (1983), obtained in piglets fed a protein-deficient milk (88\%), suggests that the protein : energy ratio in sow's milk is low compared to the nutrient requirement for maximal growth in suckling piglets. Moreover, this would explain why there is a higher proportion of fat in the body of suckled piglets at weaning than in artificially reared ones fed a protein-adequate diet (Campbell and Dunkin, 1983).

Empty body weight gain results from the deposition of water, protein, fat and ash. Therefore a linear relationship between ${ }_{E} A D G$ and nutrient deposition was calculated. In the equation, the intercept was not significantly different from zero. 
TABLE 4

Energy, nitrogen and fat balance of suckling piglets between $d 1$ and weaning at 22 days of age ( $n=20$; results correspond to a litter and are expressed per piglet per day).

\begin{tabular}{|c|c|c|}
\hline Item & Mean & $\mathrm{RSD}^{\mathrm{a}}$ \\
\hline $\begin{array}{l}\text { Growth rate: } \\
\text { Body weight at d1 }(\mathrm{kg}) \\
\text { Body weight gain }(\mathrm{g}) \\
\text { Mean body weight }(\mathrm{kg})\end{array}$ & $\begin{array}{c}1.39 \\
195 \\
3.10\end{array}$ & $\begin{array}{l}0.10 \\
6 \\
0.08\end{array}$ \\
\hline $\begin{array}{l}\text { Protein and fat balance: } \\
\mathrm{N} \text { intake from milk }(\mathrm{g}) \\
\mathrm{N} \text { retained }(\mathrm{g})^{\mathrm{b}} \\
\text { Fat intake from milk }(\mathrm{g}) \\
\text { Fat retained }(\mathrm{g})^{\mathrm{b}}\end{array}$ & $\begin{array}{l}5.43 \\
4.78 \\
53.5 \\
28.7\end{array}$ & $\begin{array}{l}0.45 \\
0.40 \\
7.0 \\
3.8\end{array}$ \\
\hline $\begin{array}{l}\text { Energy balance : } \\
\text { Energy intake as milk (kcal) } \\
\text { Heat production (kcal)c } \\
\text { Oxygen consumption (I) } \\
\text { Carbon dioxide production (I) } \\
\text { Respiratory quotient }{ }^{\mathrm{c}} \\
\text { Retained energy RO }(\mathrm{kcal})^{\mathrm{c}} \\
\text { Retained energy ST (kcal) }\end{array}$ & $\begin{array}{c}867 \\
368 \\
75.6 \\
63.4 \\
0.84 \\
456 \\
474\end{array}$ & $\begin{array}{l}82 \\
28 \\
5.8 \\
4.5 \\
0.01 \\
53 \\
48\end{array}$ \\
\hline
\end{tabular}

a Residual standard deviation from variance analysis ; ${ }^{b}$ As measured by the comparative slaughter technique ; ${ }^{c}$ Retained energy estimated as the difference between metabolizable energy intake as milk (energy as milk $\times 0.95$ ) and heat production (Brouwer, 1965); ${ }^{\mathrm{d}} \mathrm{CO}_{2} / \mathrm{O}_{2}$ ratio.

Moreover, the coefficient for ash was not significant. The final relationship was therefore :

${ }_{E} A D G=5.20( \pm 0.12) \times$ protein $+1.17( \pm 0.12) \times$ fat $R S=6.6 ; R=0.99$ (1) where ${ }_{E} A D G$, protein and fat are expressed as $g /$ day. From equation (1), it can be concluded that weight gain was highly dependent on protein accretion since the deposition of $1 \mathrm{~g}$ of protein was associated with about $4.2 \mathrm{~g}$ of water and minerals (5.20 minus 1). Slightly lower values have been obtained in growing pigs (Just, 1984) and in early-weaned piglets (Noblet and Le Dividich, unpublished). In agreement with these authors, the deposition of $1 \mathrm{~g}$ of fat was associated with an almost similar value of ${ }_{E} A D G$.

\section{Metabolic rate.}

When expressed per $\mathrm{kg}$ of body weight, $\mathrm{O}_{2}$ consumption decreased regularly $(P<0.01)$ with piglet age (fig. 2). Similar results were obtained by Studzinski (1972). As shown in figure 2 , changes in $\mathrm{O}_{2}$ consumption $(\mathrm{ml} / \mathrm{kg} \mathrm{BW})$ were closely related to changes in milk energy intake $(\mathrm{M}, \mathrm{cal} / \mathrm{kg} \mathrm{BW})$. However, $\mathrm{O}_{2}$ consumption at $d 1$ was lower than at $d 5$, even though $M$ was higher at d1. Similar results were reported by Gentz et al. (1970) and Noblet and Le Dividich (1981). The increase in metabolic rate between $\mathrm{d} 1$ and $\mathrm{d} 5$ appeared to correspond to a period of postnatal adaptation. When d1 data were excluded, $\mathrm{O}_{2}$ consumption $\left(\mathrm{ml} . \mathrm{kg} \mathrm{BW}^{-1} \cdot \mathrm{min}^{-1}\right.$ ) 


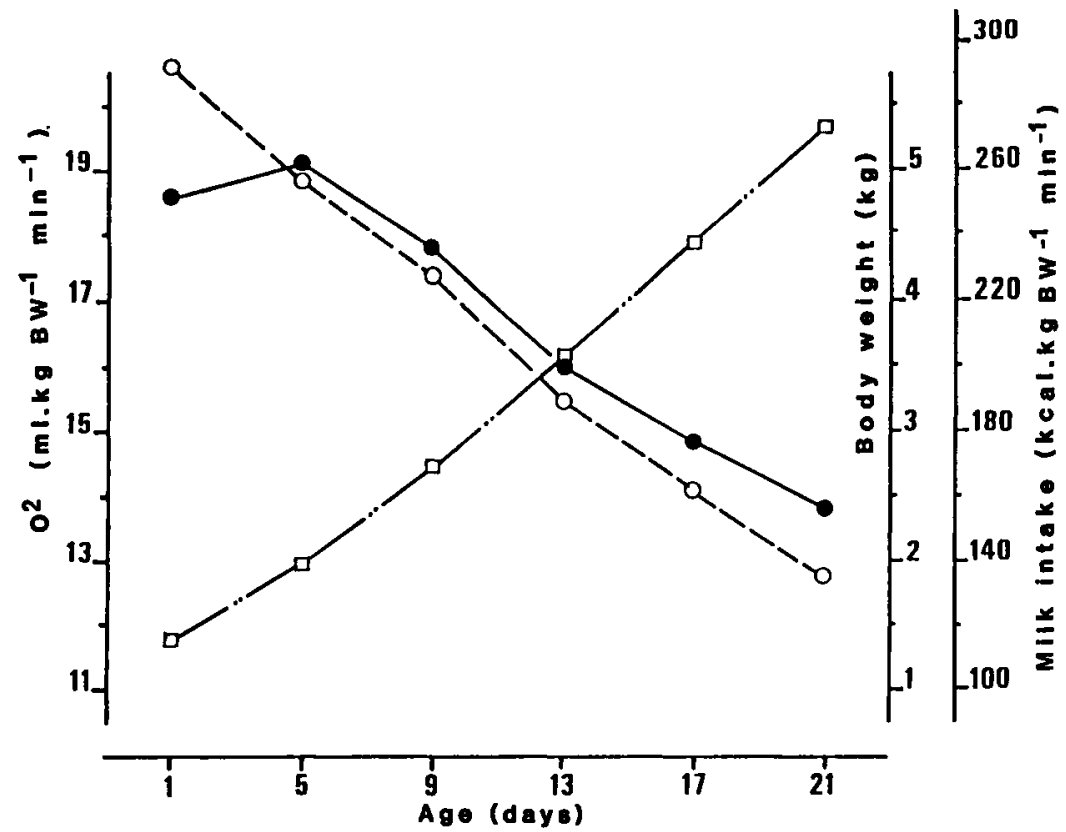

FIG. 2. - Effect of age on body weight $(\square)$, milk intake $(0)$ and oxygen consumption ( $\bullet)$ in suckling piglets.

changed with $\mathrm{BW}(\mathrm{kg})$ and $\mathrm{M}$ (cal. $\left.\mathrm{kg} \mathrm{BW}^{-1} \cdot \mathrm{min}^{-1}\right)$ according to the following equations $(\mathrm{n}=110)$ :

$\mathrm{O}_{2}$ consumption $=21.58-1.48( \pm 0.09) \times \mathrm{BW} \quad \mathrm{RSD}=1.2 ; \mathrm{R}=0.84$ (2)

$\mathrm{O}_{2}$ consumption $=10.22+0.031( \pm 0.003) \times \mathrm{M} \quad \mathrm{RSD}=1.5 ; \mathrm{R}=0.72$ (3)

In order to partition $\mathrm{O}_{2}$ consumption between $\mathrm{O}_{2}$ consumption related to maintenance requirements (i.e. a function of metabolic body weight) and that related to heat increment of feeding (i.e. a function of milk intake), a multiple regression was calculated according to the following model :

$\mathrm{O}_{2}$ consumption $=\mathrm{a} \times \mathrm{BW}^{\mathrm{b}}+\mathrm{c} \times \mathrm{M}$

where all data are expressed per day and per piglet and $\mathrm{O}_{2}$ consumption as liters, $B W$ as $\mathrm{kg}$ and $M$ as kcal. Since $M$ and $B W$ were highly correlated $(r=0.72)$, the coefficient $\mathrm{c}$ was not significant. The equation was therefore $(n=110)$ :

$\mathrm{O}_{2}$ consumption $=34.4\left( \pm 0.9 \times \mathrm{BW}^{0.68} \pm 0.02\right) \mathrm{RSD}=5.5 ; \mathrm{R}=0.96(4)$ where $\mathrm{O}_{2}$ consumption liters/day) ranged from 36.4 to 123.4 (mean : 80.8) and $\mathrm{BW}$ $(\mathrm{kg})$ from 1.6 to 6.2 (mean : 3.6 ). This equation does not allow estimates of maintenance requirements and heat increment of feeding over that period of growth. However, energy metabolism is more precisely correlated to $\mathrm{BW}^{0.68}$ than to usual metabolic body size (RSD $=6.0$ in equation (4) with BW 0.75 ). Such conclusion in growing animals was reported by Baldwin et al. (1984). In addition, when expressed per $\mathrm{kg} \mathrm{BW} 0.68, \mathrm{O}_{2}$ consumption appears constant over the suckling period. Similar results have been reported by Degen and Young (1982) in suckling 
lambs. In the present experiment, the respiratory quotient (RQ) was not affected by lactation stage and averaged 0.84 . This low value of $R O$ appears to be related to the high fat percentage of sow's milk and to the large proportion of milk fat catabolized for energy purposes (table 4). $\mathrm{HP}$ could be predicted from $\mathrm{O}_{2}$ consumption and $\mathrm{CO}_{2}$ production by Brouwer's formula (1965). Since the $\mathrm{RO}\left(\mathrm{CO}_{2} / \mathrm{O}_{2}\right)$ was constant over lactation, $\mathrm{HP}$ could be calculted from $\mathrm{O}_{2}$ consumption only with $4.87 \mathrm{cal} / \mathrm{ml}$ of $\mathrm{O}_{2}$ as the calorific value. In these conditions, HP averaged $168 \mathrm{kcal} / \mathrm{kg}$ BW.68 over lactation.

$\mathrm{O}_{2}$ consumption and HP between $\mathrm{d} 1$ and weaning were calculated for each litter (table 4). Individual data presented in figure 3 clearly show the linear relationship between $\mathrm{O}_{2}$ consumption or $\mathrm{HP}$ and the ADG of the litter. The equations were :

$\mathrm{O}_{2}$ consumption $=14.2+0.315( \pm 0.035) \times$ ADG $\mathrm{RSD}=3.7 ; \mathrm{R}=0.90(5)$ $\mathrm{HP}=68.0+1.54( \pm 0.15) \times$ ADG RSD $=17.4 ; \mathrm{R}=0.91(6)$

with $\mathrm{O}_{2}$ consumption expressed as liters.day ${ }^{-1}$. piglet $^{-1}$, HP as kcal.day ${ }^{-1}$.piglet $^{-1}$ and $A D G$ as g. day ${ }^{-1}$. piglet ${ }^{-1}$. For practical purposes, $\mathrm{O}_{2}$ consumption (and $\mathrm{CO}_{2}$ production) of the litter over a 21-day lactation could then be predicted from piglet growth rate (equation 5). Similarly, piglet $\mathrm{O}_{2}$ consumption could be estimated at any time during the suckling period (d5 to d21) from equations (2) or (4).

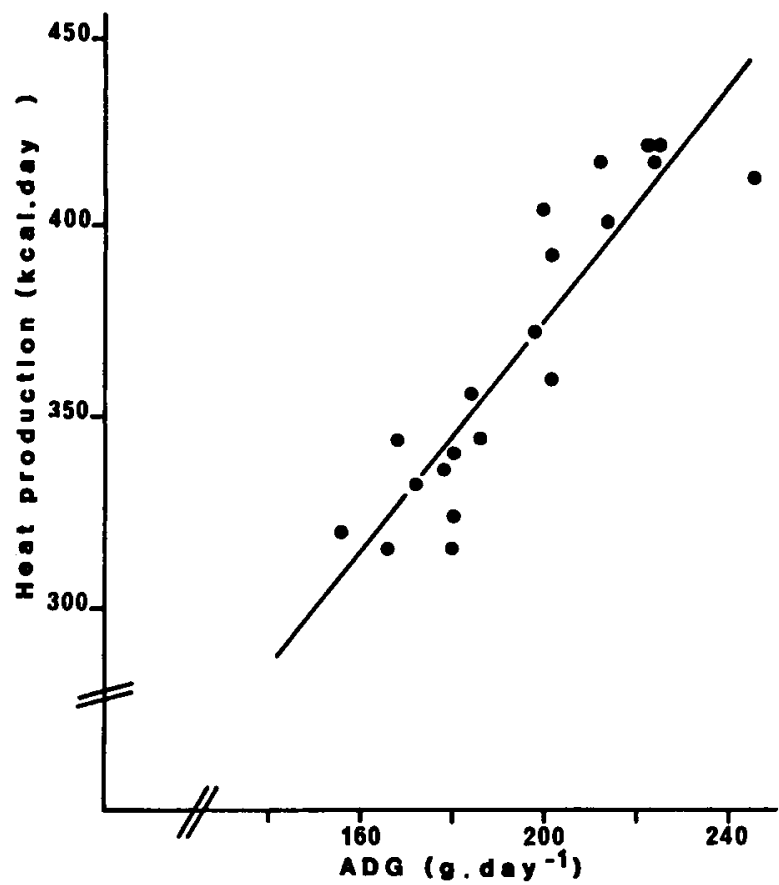

FIG. 3. - Relationship between heat production and daily growth rate (ADG) in suckling piglets. Each point corresponds to one litter from the day after birth to weaning at 22 days and is expressed per piglet and per day. 
The difference between energy intake as milk and HP from d1 to weaning, calculated for each litter, provided an estimate of retained energy $\left(E R_{R O}\right)$. A further estimate of retained energy was the difference between the energy content of the litter at weaning and at $\mathrm{d} 1\left(E R_{\mathrm{ST}}\right)$. Mean results expressed per piglet per day are shown in table 4 . The discrepancy between the two estimates of retained energy was $3.8 \%$ of $E R_{\mathrm{ST}}$. This difference is rather small compared to those reported for growing animals (Just et al., 1982). Moreover, in contrast to usual findings, $E R_{\mathrm{RO}}$ was lower than $E R_{\mathrm{ST}}$. This could be explained in part by the probable underestimation of milk production usually observed when the weighsuckle-weigh technique is used (Pettigrew et al., 1985). This underestimation would represent about $18 \mathrm{kcal}^{\text {. piglet }}{ }^{-1} \cdot$ day $^{-1}(2 \%)$ of measured milk intake. Finally, the present results suggest that like nitrogen, milk energy is also used by suckling piglets with high efficiency. Indeed, about $55 \%$ of metabolizable energy intake was recovered in the body tissues (table 4), whereas the corresponding value for growing pigs has been reported to be as low as $40 \%$ (Noblet et al., 1987).

Reçu en novembre 1986. Accepté en avril 1987.

Résumé. Composition corporelle, production de chaleur et utilisation des nutriments du lait chez les porcelets allaités.

La consommation d'oxygène $\left(\mathrm{O}_{2}\right)$, la production de gaz carbonique $\left(\mathrm{CO}_{2}\right)$, la production de chaleur (HP) et les quantités de nutriments du lait ingérés par les porcelets de 22 portées sous la mère ont été mesurées tous les quatre jours entre le lendemain de la naissance et le sevrage effectué à l'âge de 22 jours. Au sevrage, 147 porcelets représentatifs de ces portées ont été abattus pour mesurer leur composition chimique et calculer les bilans d'énergie et de nutriments des porcelets et des portées entre la naissance et le sevrage. Quand on les rapportait au poids vif ${ }^{0,68}, \mathrm{O}_{2}, \mathrm{CO}_{2}$ et $\mathrm{HP}$ demeuraient constants pendant toute la durée d'allaitement : $\mathrm{O}_{2}$ et $\mathrm{HP}$ s'élevaient en moyenne à respectivement $34,4 \mathrm{I}$ et à $168 \mathrm{kcal} \cdot \mathrm{kg}^{0,68}$.jour ${ }^{-1}$. Le quotient respiratoire $\left(\mathrm{CO}_{2} / \mathrm{O}_{2}\right)$ était de 0,84 . La vitesse de croissance entre la naissance et le sevrage (ADG) variait de 35 a $285 \mathrm{~g} / \mathrm{jour}$ (186 g/jour, en moyenne). Les teneurs en matière sèche, lipides et énergie des porcelets au sevrage étaient corrélées positivement avec ADG tandis que les teneurs en protéines et en minéraux étaient corrélées négativement avec ADG. Les quantités de protéines, de lipides, de minéraux et d'énergie déposées quotidiennement variaient de façon linéaire avec ADG. Aussi la composition chimique du gain marginal était-elle constante : $410,141,197$ et $28 \mathrm{mg} / \mathrm{g}$ et $2960 \mathrm{cal} / \mathrm{g}$ respectivement pour la matière sèche, les protéines, les lipides, les minéraux et l'énergie. La fixation d'1 $\mathrm{g}$ de protéines ou d'1 $\mathrm{g}$ de lipides étaient associées à un gain pondéral respectif de $5,20 \mathrm{~g}$ ou de $1,17 \mathrm{~g}$. Enfin, $55 \%$ de l'énergie et $85 \%$ de l'azote apportés par le lait étaient retenus dans le gain de poids des porcelets.

\section{References}

BALDWIN B. R., FORSBERG R. E., HU C. Y., 1984. Potential for altering energy partition in the lactating cow. J. Dairy Sci, 68, 3394-3402.

BERGE S., INDREB $\emptyset$ T., 1954. Composition of body and weight gain of suckling pigs. Meld. Nor. Landbrukshogsk., 33, 481-500.

BLIGH E. G., DYER W. I., 1959. A rapid method of total lipid extraction and purification. Can. J. Biochem. Physiol., 37, 911-917. 
BROUWER E., 1965. Report of sub-committee on constants and factors. In BLAXTER K. L., Energy metabolism, EAAP No 11, 441-443, Acad. Press, London.

CAMPBELL R. G., DUNKIN A. C., 1983. The effect of energy intake and dietary protein on nitrogen retention, growth performance, body composition and some aspects of energy metabolism of baby pigs. Br. J. Nutr., 49, 221-230.

CAMPBELL R. G., TAVERNER M. R., CURIC D. M., 1985. Effect of sex and energy intake between 48 and $90 \mathrm{~kg}$ live weight on protein deposition in growing pigs. Anim. Product., 40, 497-503.

DEGEN A. A., YOUNG B. A., 1982. Intake energy, energy retention and heat production in lambs from birth to 24 weeks of age. J. anim. Sci., 54, 353-362.

ELSLEY F. W. H., 1964. The physiological development of the young pig. Ann. Zootech., 13 (HS 1), 75-84.

GENTZ J., BENGTSSON G., HAKKARAINEN J., HELLSTROM R., PERSSON B., 1970 . Factors influencing oxygen consumption in the newborn pig with special reference to feeding. Biol. Neonate, 16, 328-342.

JORDAN J. W., BROWN W. O., 1970. The retention of energy and protein in the baby pig fed on cow's milk. In SCHURCH A., WENK C., Energy metabolism of farm animals, EAAP No 13 , 161-165, Juris Druck Verlag, Zürich.

JUST A., 1984. Nutritional manipulation and interpretation of body compositional differences in growing swine. J, anim. Sci., 58, 740-752.

JUST A., FERNANDEZ J. A., JORGENSEN H., 1982. Nitrogen balance studies and nitrogen retention. In LAPLACE J. P., CORRING T., RÉRAT A., Digestive physiology in the pig, Les Colloques de I'I.N.R.A., 12, 111-122.

MANNERS M. J., MCCREA M. R., 1963. Changes in the chemical composition of sow-reared piglets during the 1st month of life. Br. J. Nutr., 17, 495-513.

MOUNT L. E., 1968. The climatic physiology of the pig. 271 p. Arnold E. Publ., London.

NOBLET J., LE DIVIDICH J., 1981. Energy metabolism of the newborn pig during the first $24 \mathrm{~h}$ of life. Biol. Neonate, 6, 324-339.

NOBLET J., ETIENNE M., 1986. Effect of energy level in lactating sows on yield and composition of milk and nutrient balance of piglets. J. anim. Sci., 63, 1888-1896.

NOBLET J., ETIENNE M., 1987. Metabolic utilization of energy and maintenance requirements in lactating sows. J. anim. Sci., 64, 774-781.

NOBLET J., HENRY Y., DUBOIS S., 1987. Influence des teneurs respectives en protéines et en lysine du régime sur les performances et l'utilisation de l'énergie par le porc en croissance. Journées Rech. porcine en France, 19, 259-264.

PETTIGREW J. E., SOWER A. F., CORNELIUS S. G., MOSER R. L., 1985. A comparison of isotope dilution and weigh-suckle-weigh methods for estimating milk intake by pigs. Can. J.anim. Sci., 65, 989-992.

ROBELIN J., VILLETTE Y., ETIENNE M., 1984. Croissance et développement corporel au cours de la période périnatale. In JARRIGE R., Physiologie et pathologie périnatales chez les animaux de ferme, 83-93. I.N.R.A., Paris.

STUDZINSKI T., 1972 . The post-natal changes in minimal metabolic rate in the pig. J. Physiol., 224, 305-316. 